\title{
POSSIBLE PHAGOCYTOSIS BY KERATINOCYTES: ULTRASTRUCTURAL EVIDENCE FROM THE STUDY OF HUMAN ORAL MUCOSA IN ORGAN CULTURE
}

\author{
D. K. MacCallum
}

Laboratory of Cell Biology, Dental Research Institute; and Department of Anatomy, Medical School, University of Michigan, Ann Arbor, Michigan 48104, U.S.A.

and

\section{J. SCALETTA}

School of Dentistry, Case Western Reserve University, Cleveland, Ohio 44106, U.S.A.

\begin{abstract}
Summary-Surgical samples of human oral mucosa undergo striking transformations within $24 \mathrm{hr}$, when maintained in organ culture, at $37^{\circ} \mathrm{C}$, on fibrin foam mats, with 5 per cent $\mathrm{CO}_{2}$ in air as the atmosphere. These transformations include disorganization of the tonofibrillar apparatus, reduction or loss of desmosomes, and loss of the intercellular relationships characteristic of stratified squamous epithelium. Under these conditions, remnants of whole, nucleated cells or fragments of nuclei were observed in membrane-bound vacuoles within keratinocytes. The ingestion of cells or cell fragments by keratinocytes usually resulted in some damage to the cytoplasm immediately adjacent to the phagocytic vacuoles containing the cells or cell fragments. While instances of keratinocyte phagocytosis were rare in the system studied, they, nevertheless, contribute additional support to previous descriptions of keratinocyte phagocyte capability. It also appears, that, while being able to phagocytose and degrade both cells and extracellular products, keratinocytes do so at the partial expense of their own structural integrity.
\end{abstract}

THE ability to phagocytose cells, cellular debris, or large, extracellular polymers such as collagen, or fibrin, is usually ascribed solely to the cells of mesodermal origin, referred to collectively as the reticulo-endothelial system, or system of macrophages. However, observations initially made on amphibians (TABAN, 1955), and later in man (ODLAND and Ross, 1968) and mouse (CROFT and TARIN, 1970), indicated that epidermal cells are capable of phagocytosis during the process of wound healing. In the latter instances, membrane-bound inclusions of fibrin and serum protein (ODLAND and Ross, 1968), and red blood cells and ingested fibrin (CROFT and TARIN, 1970), were observed by electron microscopy. At the same time, MotTAZ and ZeLICKson (1970) reported the presence of Langerhans cell fragments within phagocytic vacuoles of keratinocytes, following tape stripping of human epidermis. Additionally, WolfF and HönigsmanN (1971) and WolfF and KonRad (1972) demonstrated ultrastructurally the ingestion, and subsequent sequestration within phagolysosomes, of both thorotrast and latex beads in guinea-pig keratinocytes. 
During a series of experiments conducted to determine optimum conditions for maintaining human oral mucosa in organ culture, we found one set of conditions under which oral epithelial cells mimicked transformations exhibited by stratified squamous epithelium during wound healing (ODLAND and Ross, 1968; CrofT and TARIN, 1970), and certain dysplasias (BRODY, 1970). These transformations include disorganization of the tonofibrillar apparatus, reduction or loss of desmosomes, and loss of the normal intercellular relationships characteristic of stratified squamous epithelium.

The specimens used in this investigation were derived from clinically non-inflamed adult human oral mucosa, obtained during oral surgical procedures. Immediately upon surgical removal, specimens were placed in a sterile solution of Ham's Nutrient Mixture F12 and transported to the laboratory. They were then washed in 2 changes of cold phosphate buffered saline and cut aseptically into tissue slices measuring approximately $2 \times 2 \times 1.5 \mathrm{~mm}$. Tissue slices were placed with the connective tissue side down on fibrin foam mats (KaLUš, 1966) in Falcon organ culture dishes, containing approximately $1 \mathrm{ml}$ of Nutrient Mixture F12 supplemented with 10 per cent foetal calf serum. Tissue slices were maintained at $37^{\circ} \mathrm{C}$ at the liquid-gas interface, in 5 per cent $\mathrm{CO}_{2}$ in air, used to adjust the $\mathrm{pH}$ to approximately $7 \cdot 3$. Tissues were removed for fixation at intervals varying from 4 to $48 \mathrm{hr}$ after initiation of the cultures.

Tissue slices were fixed at room temperature for $2 \mathrm{hr}$ in 2.5 per cent glutaraldehyde in $0.05 \mathrm{M}$ phosphate buffer ( $\mathrm{pH} \mathrm{7.3)} \mathrm{containing} 4.5$ per cent sucrose. The fixed tissue was rinsed in $0 \cdot 1 \mathrm{M}$ phosphate buffer, followed by postfixation in 1 per cent $\mathrm{OsO}_{4}$ in the same buffer. The tissues were subsequently stained en bloc with 2 per cent uranyl acetate (KARNOVSKY, 1967), prior to dehydration through ethyl alcohol and propylene oxide. Embedding was in a mixture of Maraglas and D.E.R. 732 (ERLANDSON, 1964). Sections from eleven experiments were viewed with a Philips EM 300 electron microscope.

By 18-24 hr after initiating organ culture, the epithelium had undergone transformation and bore little resemblance to the normal histology of stratified squamous epithelium. Concomitant with disorganization of the tonofibrillar apparatus and reduction or loss of desmosomes, the epithelial cells either had become spherical or demonstrated an irregular polygonal shape (Fig. 1, inset). Ultrastructural examination of such cultures revealed a number of unusual inclusions within the cytoplasm of the epithelial cells. The nature of many inclusions could not easily be determined; however, in a very few instances, remnants of what appeared to be nucleated cells could be observed within keratinocytes (Fig. 1). All the ingested cells were in advanced stages of degeneration, and were usually contained within a single membrane-bound vacuole. In some regions, the vacuolar membrane surrounding the ingested cell could not be demonstrated. The absence of this vacuolar membrane usually was associated with what appeared to be erosion of the cytoplasm belonging to the ingesting cell (Fig. 2). Remnants of nuclei could also be observed in single smaller vacuoles contiguous with other membrane-bound vacuoles containing a mixture of membranes and flocculent material of moderate electron density (Fig. 3). Occasionally, cell organelles or ground cytoplasm adjacent to these smaller vacuoles appeared to be damaged (Fig. 3).

Except for the very specialized heterophagic transfer of pigment between melano- 
cytes and keratinocytes, phagocytosis has not been reported to be a feature of normal stratified squamous epithelium. Our finding of nucleated cells being ingested by keratinocytes adds an additional dimension to the earlier wound healing (ODLAND and Ross, 1968; Croft and TARIN, 1970), tape stripping (MotTAZ and Zelickson, 1970). and exogenous particulate experiments (WOLFF and HöNIGSMANN, 1971; WolfF and KonRAD, 1972), which have clearly demonstrated keratinocyte phagocytosis. The conditions which seem to permit keratinocyte phagocytosis appear to be related to the loosening of epithelial cells, for in most instances where phagocytosis has been observed, loosening of cells associated with epithelial migration or widened intercellular spaces and villus-like cytoplasmic projections have been described. This loosening of cells with attendant villus-or pseudopodal activity, as observed previously by others and in the present study, may promote ingestive behaviour.

Previous investigators have not recorded the frequency of phagocytosis by keratinocytes, with the exception of MoTTAZ and ZeLICKSON (1970), who reported "many" keratinocytes possessed phagocytic vacuoles containing recognizable cell parts $48 \mathrm{hr}$ after tape stripping. In our studies, such phagocytic behaviour must be recorded as rare, insofar as observing recognizable cellular constituents which had been ingested by epithelial cells. The cytoplasm of many epithelial cells maintained under the particular organ culture conditions described did contain vacuoles which possessed degenerating materials. However, we are uncertain whether these vacuoles were the result of phagocytosis or autophagy.

We have not seen any epithelial cells engaged in the initial stages of phagocytosis. Therefore, it is uncertain whether the cells observed had ingested a viable cell, and subsequently destroyed it, or whether only dead cells were ingested. A third mechanism exists which could explain the presence of a dead cell within the cytoplasm of a keratinocyte. This would involve the penetration of the keratinocyte cytoplasm by another cell, which subsequently became trapped and died. Such a process, termed emperiopolesis, has been observed in tissue culture many times (TroweLl, 1965); however, the penetrating cell is usually a lymphocyte which has a smaller size and different nuclear morphology than the cells observed by us.

In our study, there always some damage to keratinocytes which exhibited phagocytosis. This ranged from damaged organelles adjacent to the ingested material to what appeared to be erosion of the cytoplasm. Similar types of cytoplasmic damage have been depicted by 2 previous investigators (MOTTAZ and ZeLICKSON, 1970; WOLFF and HÖNIGSMANN, 1971). While the partial absence of the vacuolar membranes and the bulging of cytomembranes into the vacuolar space might be considered an artifact, we consider this unlikely since membrane discontinuities are not associated with the type of fixation used in this study. Thus, it would appear that while being able to phagocytose and degrade both cells and extracellular products, keratinocytes do so at the partial expense of their own structural integrity.

Acknowledgements-We wish to thank Dr. Thomas J. DeMarco for supplying the tissue used in the experiments, Drs. B. TANDLER and S. S. HAN for criticisms of the manuscript, and O. S. PARK and E. K. PARK for technical and photographic assistance. 
This study was supported by DE 03393, DE 02731, DE 02697, DE 32968 and an allocation from Institutional Research Grant IN 40-K from the American Cancer Society to the University of Michigan.

\begin{abstract}
Résumé-Des spécimens chirurgicaux de muqueuse orale humaine subissent des transformations frappantes à moins de $24 \mathrm{hr}$, quand maintenus en cultures d'organes a $37^{\circ} \mathrm{C}$, sur des nattes de mousse de fibrine avec 5 pour cent $\mathrm{CO}_{2}$ dans l'air, comme atmosphère. Ces transformations incluent la désorganisation de l'appareil tonofibrillaire, la réduction ou la perte de desmosomes et la perte des rapports caractéristiques intercellulaires de l'épithélium squameux stratifié. Sous ces conditions, des restes de cellules entières nucléées ou des fragments de noyaux peuvent être observés dans des vacuoles liées aux membranes, à l'intérieur cdes kératinocytes. L'ingestion de cellules ou de fragments de cellules par les kératinocytes résulta d'habitude dans un certain dégât à la cytoplasme, immédiatement adjacente aux vacuoles phagocytiques, contenant des cellules ou des fragments de cellules. Tandis que les cas de phagocytose des kératinocytes étaient rares dans le système étudié, néanmoins ils donnent un soutien supplémentaire aux descriptions antérieures de capacité phagocytique des kératinocytes. Il apparait aussi que, tout en étant capable de phagocyter et dégrader les cellules et les produits extracellulaires, les kératinocytes le font aux dépens partiels de leur propre intégrité structurale.
\end{abstract}

\begin{abstract}
Zusammenfassung-Chirurgische Proben von menschlicher Mundmukosa unterliegen innerhalb von 24 Stunden auffallenden Veränderungen, wenn sie in Organkultur bei $37^{\circ} \mathrm{C}$ auf Fibrinschaumgeflecht mit 5 Prozent $\mathrm{CO}_{2}$ in Luft als Atmosphäre erhalten werden. Zu den Veränderungen gehören Disorganisierung des Tonofibrillenapparates, Reduzierung oder Verlust von Brückenkörperchen und Verlust der interzellulären Beziehungen, die dem stratifizierten Plattenepithel eigentümlich sind. Unter diesen Umständen konnten Reste ganzer kernhaltiger Zellen oder Kernfragmente in Membranvakuolen innerhalb der Keratinozyten beobachtet werden. Die Einnahme von Zellen oder Zellfragmenten durch Keratinozytrn verursachte im allgemeinen gewissen Schaden in dem Zytoplasma, das direkt an den Phagozytosevakuolen anliegt, welche die Zellen oder Zellfragmente enthielten. Während Vorkommen von Keratinozytenphagozytose in dem untersuchten System selten waren, stützen sie trotzdem weiterhin frühere Beschreibungen von Fähigkeit der Keratinozyten-Phagozyten. Während Keratinozyten im Stande sind, sowohl Zellen und extrazelluläre Produkte zu phagocytieren und zu entarten, so tuen sie dies scheinbar teilweise auf Kosten ihrer eigenen strukturellen Integrität.
\end{abstract}

\title{
REFERENCES
}

Brody, I. 1970. Contributions to the histogenesis of basal cell carcinoma. J. ultrastruct. Res. 33, 60-79.

Croft, C. B. and TARIN, D. 1970. Ultrastructural studies of wound healing in mouse skin. I. Epithelial behaviour $J$. Anat. 106, 63-77.

ERLandson, R. A. 1964. A new Maraglas, D.E.R. 732, embedment for electron microscopy. J. Cell Biol. 22, 704-706.

KALUš, M. 1966. Cultivation of organ fragments on fibrin foam. Folia Biologica (Praha) 12, 468-472.

KaRnovsky, M. G. 1967. The ultrastructural basis of capillary permeability studied with peroxidase as a tracer. J. Cell Biol. 35, 213-236.

MotTAZ, J. H. and Zelickson, A. S. 1970. The phagocytic nature of the keratinocyte in human epidermis after tape stripping. $J$. invest Dermatol. 54, 272-278.

Odland, G. and Ross, R. 1968. Human wound repair. I. Epidermal regeneration. J. Cell Biol. 39, $135-151$.

TABAN, C. 1955. Quelques problemes de regeneration chez les urodeles. Rev. Suisse Zool. 62, 387-468.

Trowell, O. A. 1965. Lymphocytes. In: Cells and Tissues in Culture (edited by Willmer, E. M.), Vol, 1, pp. 96-172. Academic Press, New York. 
WolfF, K. and Hönigsmann, H. 1971. Permeability of the epidermis and phagocytic activity of keratinocytes. J. ultrastruct. Res. 36, 176-190.

WolfF, K. and KonRAD, K. 1972. Phagocytosis of latex beads by epidermal keratinocytes in vivo. J. ultrastruct. Res. 39, 262-280.

Plaie 1 overleaf 


\section{Plate 1}

Fig. 1. Inset. A light micrograph of an 18-hr culture. Many of the cells at the base of the epithelial peg are spherical and demonstrate increased intercellular distances. The epithelial cells located toward the surface are spaced more closely and are irregularly shaped. The transformation from the ordered, stratified organization associated with this type of tissue is evident. Toluidine blue $0 . \times 400$

FIG. 1. Low-power electron micrograph taken from a region and time period comparable to that shown in the inset. A degenerating, nucleated (N) cell is located within a vacuole (V) of an epithelial cell. A portion of a degenerating cell (DC) located between two epithelial cells is also evident. The abundant tonofibrils within the viable cells and the presence of desmosomes (D), although poorly formed, clearly establishes the epithelial nature of these cells. Uranyl acetate and lead citrate. $\times 14,400$ 


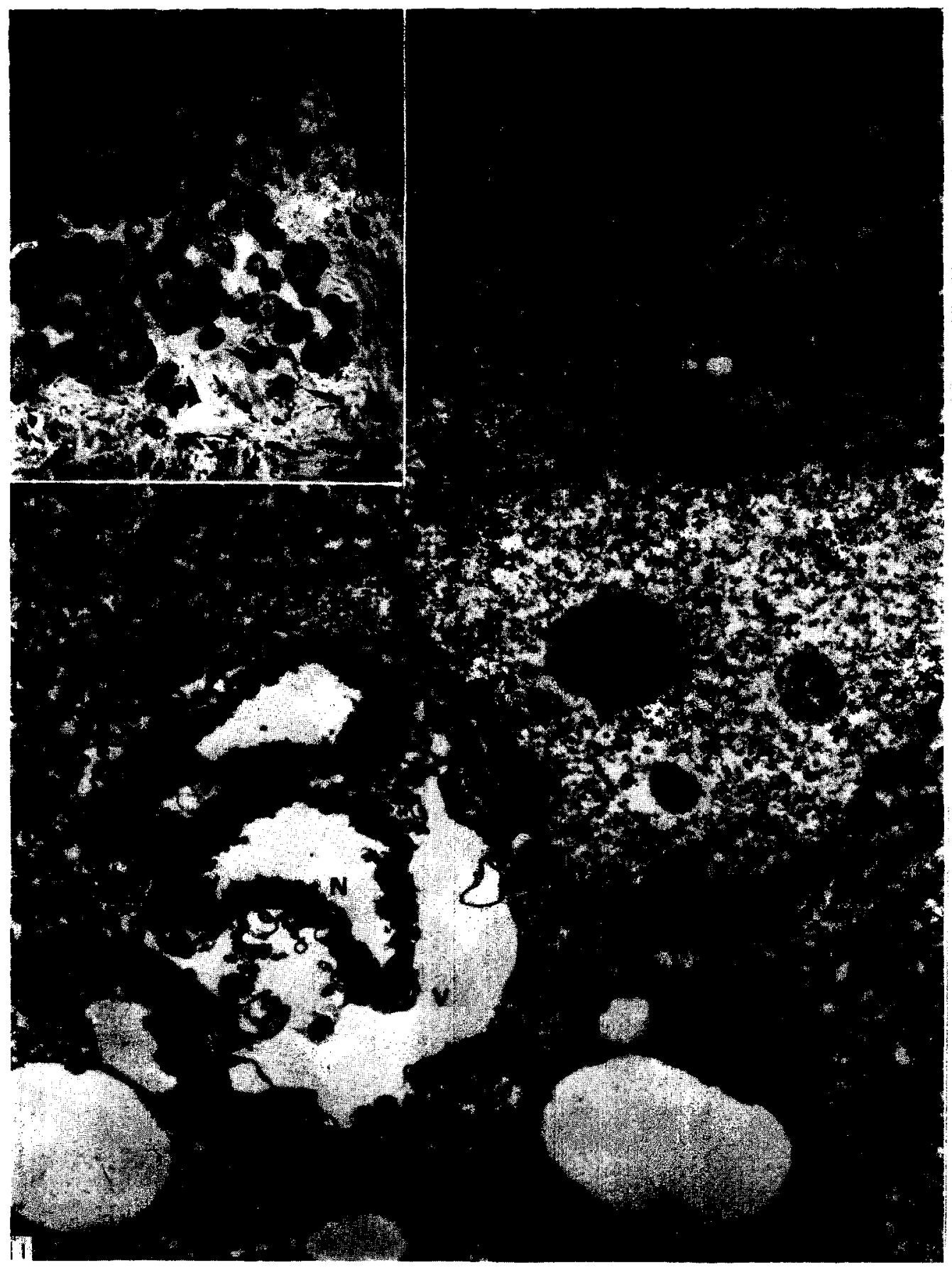

Pl.ATH: 1

A.O.B. f.p. 454 


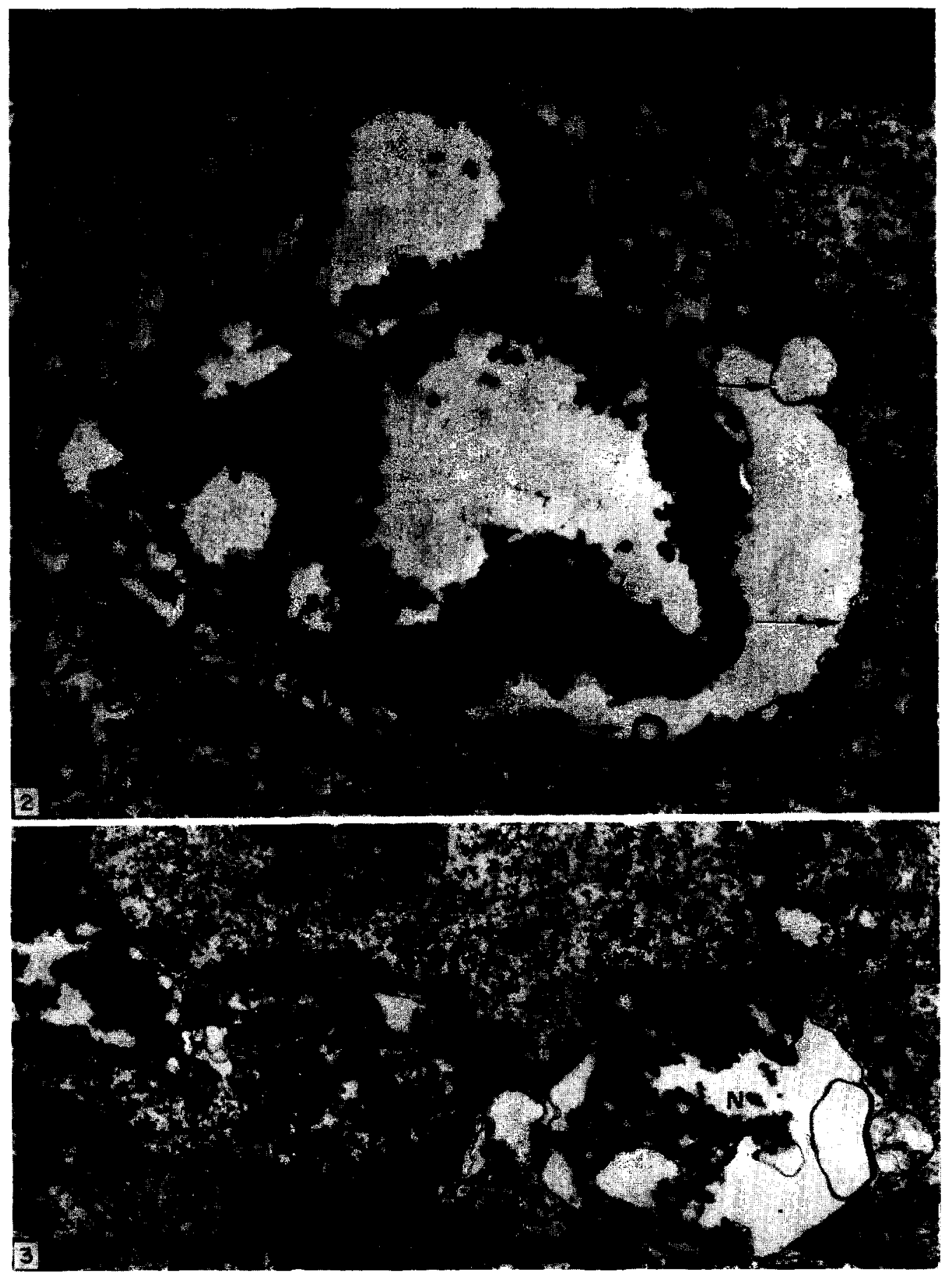

Pi.ate 2 


\section{Plate 2}

FIG. 2. A higher power electron micrograph of a section taken approximately $0.4 \mu \mathrm{m}$ distant from the one in Fig. 1. In the area of the vacuole where a bounding membrane is absent, several membranous elements (arrows) belonging to the ingesting cell appear to be herniating into the vacuolar space. This may represent true erosion of the cytoplasm. Several other regions (A,B,C) of the cytoplasm separated from the degenerating cell by a vacuolar membrane also appear disorganized. Uranyl acetate and lead citrate. $\times 24,300$

FIG. 3. Three material-filled vacuoles are present within the cytoplasm of a keratinocyte. One of the vacuoles $(\mathrm{N})$ contains material resembling portions of the degenerating nucleus in Fig. 2. Adjacent sections were filled with large electron-opaque regions identical with those of the nucleus in Fig. 2. Mitochondria adjacent to the vacuoles appear to be damaged. Uranyl acetate and lead citrate. $\times 24,300$ 